JANINA USZYŃSKA-JARMOC ${ }^{1}$

BEATA KUNAT ${ }^{2}$

MONIKA ŻAK-SKALIMOWSKA ${ }^{3}$

\title{
The Need for Cognition and Meta-learning Competence among Students of Teacher Education at the University Level
}

\begin{abstract}
Cognition and meta-learning competencies are important elements in teacher education programs. The research presented was aimed at discovering the link between the need for cognition and meta-learning competence. The research sample comprised 250 students of teacher education in their first-year of study for the degree of licencjat (Bachelor's equivalent) and magister (Master's equivalent). Research findings demonstrate the existence of 1) a correlation between the students' need for cognition and their meta-learning competence, 2) differences between students at the Bachelor's and Master's level of education with regard to their expressed need for cognition and meta-learning competence (including subcomponents of the latter) which suggests that these needs and competencies develop over the course of their university education.
\end{abstract}

Keywords:

teacher education, motivation, need for cognition, metacognition, competence of meta-learning

1 Faculty of Pedagogy and Psychology, University of Białystok, Poland. E-MAIL: j.uszynska@uwb.edu.pl ORCID: 0000-0002-9078-5096

2 Faculty of Pedagogy and Psychology, University of Białystok, Poland. E-MAIL: b.kunat@uwb.edu.pl ORCID: 0000-0002-5205-1366

3 Faculty of Pedagogy and Psychology, University of Białystok, Poland. E-MAIL: m.zak@onet.pl ORCID: 0000-0002-0235-782 


\section{INTRODUCTION}

Numerous academic publications emphasize the need to modify the methodology and program content for preparing students to work in nursery schools and years I-III of elementary school, in order that the teaching is appropriate in terms of meeting the challenges of our ever changing, globalized and computerised world (Auerbach, 2015; Biesta, 2012; Gaikhorst, Beishuizen, Roosenboom, \& Volman, 2017; McGlynn-Stewart, 2015; Scager, Akkerman, Pilot, \& Wubbels, 2017; Snider \& Roehl, 2007).

We think of our societies as "knowledge societies" in which lifelong learning is becoming increasingly important. Lifelong learning refers to the idea that people learn not only in schools and at universities, but also in non-formal and informal ways, throughout their lives (Carneiro, 2007, 2011; Scott, 2015; Steffens, 2015). One of the tasks of university education is to prepare the student - the future teacher of early years' education - to engage in constant, autonomous, self-regulated learning, with the aim of perfecting or modifying his/her professional competencies acquired within the framework of university education (Arpaci \& Bardakçi, 2016; Farrell \& Jacobs, 2016; Haynes \& Brown Leonard, 2010; Steffens, 2015). It is also important that newly qualified teachers who want to continue learning as they pursue their professional careers can work in an interdisciplinary team comprising experts in other fields: psychologists, speech therapists, doctors, social workers and members of the school administration. Hence, such teachers should be willing and able to pursue interdisciplinary studies within the context of their social and internet networks (Boix Mansilla \& Duriasing, 2007; Clark \& Wallace, 2015; Farrell \& Jacobs, 2016; Postholm, 2012; Spelt, Luning, van Boekel, \& Mulder, 2017).

At the beginning of their professional career, teachers must undertake autonomous and responsible learning, not only because contemporary reality is changing (Jakobi \& Rusconi, 2009), but also because the teachers of today face problems which they never had to solve as part of their university training (Bruinsma \& Jansen, 2010; Daghistani, 2015; Robin \& Margalef, 2013; Scager, Akkerman, Pilot, \& Wubbels, 2017). Many research papers emphasize the fact that newly qualified teachers encounter three kinds of difficulty: (1) a shift in their role from student to teacher; (2) conflicts between desired and actual support given to students; and (3) conflicting concepts of learning to teach (Pillen, Beijaard, \& Brok, 2013; Scager, Akkerman, Pilot, \& Wubbels, 2017; Yoon \& Kim, 2010). That is why it is so important that students learn on the job, inter alia from their own action research and subsequent sharing of the results, personal experiences and educational perspectives with other team members. Learning in this way, students 
are stimulated to take increasingly rational educational decisions and to transform the attitudes manifested up to that moment in their educational relationship with students (Kara, 2009; Kelchtermans, 2009; Lamote \& Engels, 2010; Postholm, 2012; Ronfeldt, Farmer, McQueen, \& Grissom, 2015; Snider \& Roehl, 2007).

\section{THEORETICAL BACKGROUND}

In order to conceptualize the challenges involved in educating future teachers, we draw on psychological theories that include the notion of challenge, such as the selfdetermination theory of motivation (SDT) (Deci \& Ryan, 1985) and the theory of social constructivism and connectivism (Aksal, Gazi, \& Bahçelerli, 2013; Bruner, 1996; Clarà \& Barberà, 2014; Farrell \& Jacobs, 2016; Fox, 2001; Siemens, 2005). SDT emphasizes the importance of intrinsic motivation. The latter is especially important for the process of informal learning outside of school. The term extrinsic motivation refers to the performance of an activity in order to attain a separate outcome; thus, it differs markedly from intrinsic motivation, which refers to doing an activity for the satisfaction inherent in performing the activity as such (Ryan \& Deci, 2000). The developers of the theory emphasize the importance of three psychological human needs: the need for autonomy, relatedness and competence. These needs are universal: they characterise learners of all ages and are important for the processes of both formal and non-formal (lifelong) learning, as well as for the development of the competence of meta-learning. Social constructivism emphasizes the fact that, as regards learning, all cognitive functions depend on interactions with others (e.g., teachers, peers and parents). Therefore, learning is dependent on the characteristics of collaborative processes taking place in an educational community. The aforementioned processes are situation-specific and context-bound (Gergen, 1995; Farrell \& Jacobs, 2016; Fox, 2001; Panitz \& Panitz, 1996; Palincsar, 1998). Social constructivism maintains that learning is based on real-life adaptive problem solving, which takes place in a social manner through sharing experiences and discussions, in which new ideas are matched against existing knowledge, and the learner adapts rules to make sense of the world. Social constructivism trains the focus on the learner, perceived as part of his/her social group, and on learning seen as something that emerges from group interaction and not as a process which takes place within the individual. Learning is thus seen as an active and socially-engaged process (Farrell \& Jacobs, 2016; McMahon, 1997).

According to social constructivist theory, cognition and learning exist in a dialectical relationship with the social world, whereby discussion is utilised to 
resolve cognitive conflict and as a result produces higher levels of mental functioning. Conflicts are resolved through a social process and knowledge is something that is distributed across, between and within individuals and the collective. This knowledge is not transmitted from the social world to the learner, but is appropriated and transformed through an active process where individuals engage with others (McMahon, 1997). Therefore, knowledge is emergent as the learner acts upon the social context and the social context acts upon the learner (Palincsar, 1998). However, learning must also be seen as more than the assimilation of new knowledge by the individual, but also as the process by which learners are integrated into a knowledge community.

Summing up, one can assume that it is intrinsic motivation, referred to in the relevant research as the need for cognition, that is indispensable for undertaking activities aimed at acquiring knowledge of one's own learning and perfecting one's own ability for lifelong learning. This paper will focus on the relationship between the need for cognition and learning competencies - both of which are important variables in determining the appropriate performance of the teaching profession and developing professional competencies.

\section{NEED FOR COGNITION}

Need for cognition (NFC) refers to an individual's tendency to engage in and enjoy effortful cognitive processing (Cacioppo \& Petty, 1982) through the performance of complex cognitive treatments using deep holistic learning strategies to reach the top of understanding and performance levels (Cacioppo \& Petty, 1982; Daghistani, 2015). Interindividual variations in need for cognition were conceptualized as falling along a bipolar continuum (from low to high) because low need for cognition was defined as the relative absence of a person's chronic tendency to engage in and enjoy effortful cognitive activities (Cacioppo, Petty, Feinstein, \& Jarvis, 1996). Need for cognition is a well-established and often-used individual difference construct investigated in numerous research projects carried out all over the world (Fleischhauer, Strobel, Enge, \& Strobel, 2013; Wood \& Swait, 2002). More than 20 years ago there were already over a hundred research projects analysing the link between the need for cognition and various personality variables (Arpaci \& Bardakçi, 2016; Cacioppo, Petty, Feinstein, \& Jarvis, 1996; Daghistani, 2015; Del Barrio-Garcia, Arquero-Montaño, \& Romero-Frias, 2015; Efklides, 2014; Gauthier, Christopher, Walter, Mourad, \& Marek, 2006; Koch, 2003; Sadowski \& Gulgoz, 1992a, 1992b; Reinhard, 2010). The need for cognition is a frequent subject of research into learning and educational success. Studies emphasize (Cacioppo, Petty, Feinstein, \& Jarvis, 1996) that individuals high in need for cognition are characterized generally by active, exploring 
minds and, through their senses and intellect, reach and draw out information from their environment. Individuals with high need for cognition are better at remembering complex information, show a stronger need to search for new and complex information than individuals with low need for cognition, make judgments after an accurate balancing of all specific information, need strong arguments in order to be persuaded, and prefer complex to simple tasks (Cacioppo \& Petty, 1982). Need for cognition is thought to reflect a cognitive motivation rather than an intellectual ability, and thus, to be related to, but distinguishable from, ability indexes. In this sense, need for cognition is analogous to individual differences in people's motivation to engage in effortful physical endeavours, which is related to, but note the same as physical ability (Cacioppo, Petty, Feinstein, \& Jarvis, 1996; Sadowski, 1993).

\section{THE CONCEPT OF META-LEARNING}

Analyzing the scientific literature shows that researchers use the term cognition more frequently than learning, while the term meta-learning is used the least frequently. The term cognition denotes the mental activity associated with knowing, perceiving, thinking, reasoning, problem solving, and remembering (Trumbull \& Pacheco, 2005). It can refer both to the processes involved in learning and the state of one's knowledge and understanding. Cognitive processes entail the perceptual (auditory, visual and so forth) memory and organizational processes related to encoding and retrieval of memories, reasoning and problem solving (Trumbull \& Pacheco, 2005, pp. 8-9). Metacognition, on the other hand, refers to "cognition about cognition" and involves cognitive processes related to appraisal, control and/or monitoring of thinking (Flavell, 1979; Flawell, Green, \& Flawell, 1998). Metacognition refers to thinking about thinking, reflecting a person's awareness of one's cognitive abilities (Kelly \& Donaldson, 2016). Metacognition comprises, inter alia, metacognitive knowledge (beliefs about one's own cognition) and metacognitive regulation (specific processes) (Stevanovic, Lalic, Batinic, Damjanovic, \& Jovic, 2016; Wells \& Cartwright-Hatton, 2004). Research into metacognition comprises also such categories as: cognitive confidence, positive beliefs about worry, cognitive self-consciousness, negative beliefs about uncontrollability of thoughts and danger, beliefs about the need to control thoughts (Wells \& Cartwright-Hatton, 2004) and, finally, metacognitive thinking skills (referring to mental actions that an individual uses to organize, monitor, guide and control his thinking) (Daghistani, 2015). In brief, one can define metacognition as "thinking about thinking” or "cognition about cognition” (Sariçam, 2015).

Learning is another term crucial for this study. Learning can be defined as acquiring an ability to execute an act or participate in an event which was previ- 
ously beyond one's ability, at the end of a certain activity (Kara, 2009, p. 100). It can therefore be referred to as a change in the organization of one's mental structures resulting from experience, which may be expressed by new behaviours (Trumbull \& Pacheco, 2005). Learning can be seen as a mainly positive transformation involving changes in an individual's cognitive, emotional and psychomotor domains: once one has learned a definite subject, one is expected to think and behave in a different way, and one's values have changed. Learning also requires continuity, because a good learner has to make use of his/her previous experiences to adapt to new conditions and situations. Learning is not only an individual, psychological process, but also a social process involving one's direct or indirect interaction with others (Farrell \& Jacobs, 2016; Ronfeldt, Farmer, McQueen, \& Grissom, 2015).

In the context of the research presented in this study, one should emphasize the importance of cooperative learning for the development of teachers' professional competencies. Cooperative learning involves students working with their peers to learn and to enjoy learning (Farrell \& Jacobs, 2016). Social networking sites such as Facebook can help create group space for digital dialogue in which to inform, question and challenge, within a frame of connectivism as learning theory within the digital age (Aksal, Gazi, \& Bahçelerli, 2013; Clarà \& Barberà, 2014). The theory of connectivism (Clarà \& Barberà, 2014; Siemens, 2005) highlights the fact that knowledge is created not only by a social group, but also by the internet, and functions not only within a social network, but in the internet network as well. Learning or understanding of data demands many activities: preliminary processing, culling relevant information and its transformation and, finally, making informed choices about the method of its organization. Without the competence of meta-learning one cannot both successfully learn in today's globalized and computerized world and participate in both the social network of learning and the internet network.

The idea of meta-learning was used by Biggs (1985) to describe the state of being aware of, and taking control of, one’s own learning. The term meta-learning pertains to awareness and understanding of the phenomenon of learning itself as opposed to gaining knowledge about a given subject. Implicit in this definition is the learner's perception of the learning context, which includes his/her knowledge of the expectations of the discipline and, more narrowly, the demands of a given learning task. Meta-learning depends on the learner's conceptions of learning, epistemological beliefs, learning processes and academic skills, summarized here as a learning approach. a student who has a high level of meta-learning awareness is able to assess the effectiveness of his/her learning approach and regulate 
it according to the demands of the learning task. Conversely, a student who is low in meta-learning awareness will not be able to reflect on his/her learning approach or the nature of the learning task set (Biggs, 1985). According to Jackson (2004), the process of acquiring the competence of meta-learning consists of constructing knowledge about the learning process in general and about one's own learning in each particular context. It concerns developing the conviction that the way we learn and control the process has merit, fits our abilities and matches our skills, and is appropriate for the way we think and act. It also involves developing appropriate attitudes. This paper claims that developing the skill of meta-learning consists of understanding the way in which human beings learn, developing one's motivation and skill needed to regulate learning, and taking responsibility for the learning process.

To sum up the theoretical part of the paper, one must stress the fact that the definition of meta-learning competence adopted in this research characterizes it as an "intrinsically motivated, self-regulated (that is, consciously and responsibly employed) ability to plan, organize, monitor and evaluate one's learning process, its sources, context, its internal (features of personality) and external determinants, and its expected results. Meta-learning competence is therefore based on a natural, innate human capability - an inborn potential ability - to learn. It is a set of features which not only varies from one individual to another, but also changes during the course of one's life; it is therefore determined by time and developed through experience, which is why it must always be defined as dynamic” (Uszyńska-Jarmoc, in print). Acquiring meta-learning competence is a conscious and intentional cognitive activity which develops through learning about one's own learning, developing intrinsic motivation for learning, developing learning skills, and taking responsibility for learning outcomes. The development of meta-learning competence occurs through the learner's interactions with his/her environment, i.e., in a given social context. The above characterization of meta-learning competence demands a high level of cognitive need.

\section{RELATIONSHIP BETWEEN NEED FOR COGNITION AND META-LEARNING}

Analysis of the scientific literature suggests that there is no new research into the correlation between the need for cognition and the competence of meta-learning as concerns students - future teachers of young children, while the existence of a link between internal motivation and school performance (Gottfried, 1985) has been proven. The above leads one to conclude that a similar correlation may be found in studies involving students. Studies by Kara (2009, p. 100) show that individuals with a better understanding of the learning process are better at perceiving 
the nature of learning, are more open to learning, have higher expectations about what they will get from learning and exhibit less anxiety in relation to learning. Research conducted among students of early childhood education (undergraduate female students) points to the existence of a statistically significant correlation between the need for cognition and metacognitive thinking (Daghistani, 2015). As has already been stated, intrinsic motivation is an important feature of the need for cognition, while academic achievement depends not only on skills, but also attitudes towards learning. Cacioppo, Petty, Feinstein, and Jarvis (1996) analyzed the results of more than a hundred studies into the links between the need for cognition and the different dimensions of cognitive functioning conducted up to 1995, but the results do not offer unambiguous conclusions. It is therefore worth analysing findings which indicate the existence of a link between need for cognition and other variables (which, in turn, have a hypothetical influence [correlation] or are in fact components of a broadly understood meta-learning competence).

The correlation between the need for cognition and the average results attained by students (where a high score indicates high academic performance) conducted on a sample group of 164 students was $r=0.26, p<0.01$ (Cacioppo, Petty, Feinstein, \& Jarvis, 1996); in a 515-student sample (undergraduates) $r=0.14, p<0.05$ (Cacioppo \& Petty, 1982); in a 57-student sample (undergraduates) $r=0.34, p<0.05$ (Tolentino, Curry, \& Leak, 1990); and in a 207-student sample (undergraduates) $r=0.21, p<0.01$ (Waters \& Zakrajsek, 1990). The correlation between need for cognition and knowledge of important current events as tested on a group of 527 undergraduates varied between 0.10 to $0.36, \mathrm{p}<0.05$ depending on the field of study (Cacioppo \& Petty, 1982).

One of the features of the theoretical model of meta-learning competence is its functional flexibility. It may therefore be interesting to study the correlations between meta-learning competence and need for cognition. Studies conducted by Miller, Omens, and Delvadia (1991), conducted on 98 undergraduates, demonstrated very low correlation levels $(r=0.01$, ns) between the above mentioned variables.

In analyzing the main subject of this article, one cannot ignore the results of research into the correlation between the need for cognition and other personality variables, inter alia, field dependence and independence. Our perception and understanding of the process in which an individual acquires the competence of metalearning (that is, his/her independent and self-directed learning of how to learn) can also be influenced by the results obtained by Cacioppo and Petty in their research (Study 2, 1982) on a group of 419 undergraduates. The correlation between field dependence (high scores indicate a tendency to think about events in a piecemeal rather than holistic manner) and need for cognition is low $(r=0.19, \mathrm{p}<0.001)$. 
Results of studies into the evaluation research subjects give their own problem solving skills and their need for cognition can help us propose hypotheses about correlations between need for cognition and competence in learning. It seems that the ability to solve problems (including those connected to one's own learning process and one's awareness of personal effectiveness in this field) can influence the acquisition of the competence of meta-learning. It is therefore worth referring to the results of studies conducted on a sample of 52 undergraduates (Heppner, Reeder, \& Larson, 1983). The correlation between the scores obtained in the NFC questionnaire and problem solving (high scores indicate low self-appraisal of problem-solving effectiveness) was negative in this study ( $r=-0.62, p<0.001)$. Furthermore, research carried out by Njus and Johnson (2008) confirms that the need for cognition can predict the development of psychosocial identity. One can therefore conclude that cognitive need is likely to be connected with the development of teachers' identities as well.

Finally, it is worth noting that the accepted model of the structure of metalearning competence assumes self-awareness of one's own knowledge of the processes of learning about and understanding the world, and awareness that one is learning new skills. Self-awareness and assessment of one's own abilities, skills and attitudes towards learning is linked to general self-assessment. One should therefore mention the results of studies into the correlations between need for cognition and an individual's general self-assessment. Studies conducted by Osberg (1987) on 213 undergraduates (sample 1) showed that the correlation between need for cognition and self-esteem (high scores indicate a positive overall evaluation of oneself) yielded $\mathrm{r}=0.44, \mathrm{p}<0.001$; in another study (sample 2, $\mathrm{N}=66$ undergraduates) $\mathrm{r}=0.37, \mathrm{p}<0.01$; and in yet another (sample $3, \mathrm{~N}=44$ undergraduates) $\mathrm{r}=0.54$, $\mathrm{p}<0.001$. Similarly high correlation coefficients were obtained when Osberg used the same student sample, but a different method of self-assessment (Self-Esteem Scale by Rosenberg, 1965) - Pearson's $\mathrm{r}$ ranged from 0.21, ns to $0.42, \mathrm{p}<0.001$. Studies conducted by Kelly and Donaldson (2016) confirmed the link between metacognition and academic performance and academic success in a group of students - future teachers. Research on other individual-difference variables provides information about the convergent and discriminant validity of the construct of need for cognition, as well as the personality of individuals with low versus high need for cognition.

Many studies confirm the hypothesis that individuals with a high need for cognition derive more enjoyment and satisfaction from engaging in seeking information, but not all analyses conducted by Cacioppo, Petty, Feinstein, and Jarvis (1996) lead to unambiguous conclusions. The analysis of studies conducted so far 
does not indicate whether there is a link between the need for cognition and the competence of meta-learning. Among relevant studies one may also include studies analysing correlations between the need for cognition and the need for change, when treated as separate constructs (Wood \& Swait, 2002). However, the need for change investigated in the above research concerned only consumer attitudes and, more specifically, attitudes towards new products.

It may therefore be assumed that the need for cognition is a precondition for the process of learning new skills and attitudes and for constructing new knowledge. Other studies suggesting that the need for cognition and the need for the competence of meta-learning share certain components were carried out by Carnevale, Inbar, and Lerner (2011), who confirmed that need for cognition, especially some of its components such as framing and honouring sunk costs, is a precondition for the process of decision-making. It is worth stressing here that these components are also important for the learning process.

\section{PRESENT STUDY}

The research presented here provides new knowledge about the relationship between the need for cognition and learning skills. In considering these issues, the present study was an attempt to answer the following research questions:

1. Is there a significant relationship between need for cognition in university students and their competence in meta-learning?

2. What is the level of cognitive need in students - future early-childhood education teachers?

3. What is the level and structure of meta-learning competence in individuals studying for the profession of early-childhood education teachers?

4. What are the differences in the level of cognitive need between students in their first year of study for the degree of licencjat (Bachelor's degree) and in their first year of study for the degree of magister (Master's degree)? Do students in their first year of study for the degree of magister (second study cycle) show a higher level of cognitive need than students in their first year of study for the degree of licencjat (first study cycle)?

5. What are the differences in the level of meta-learning competence between students in their first year of studies for the degree of licencjat and in their first year of studies for the degree of magister? Do the magister-level students show a higher level of meta-learning competence than the licencjat-level students? 


\section{METHODS}

The main objective of this study was to examine the relationship between need for cognition and meta-learning competence and their sub-dimensions (components). The hypothesis proposed was that there is a significant and positive relationship between need for cognition and students' meta-learning competence. Students in training for the profession of teachers in early-childhood education at the licencjat-level would be expected to show a lower level of meta-learning competence and cognitive needs than those at the magister-level. It may also be assumed that students choose to continue their studies in the same field at the magister-level because they wish to deepen their knowledge and develop skills necessary for working with children in kindergarten and in grades I-III of elementary school. They would therefore be expected to have a higher level of cognitive need and a higher level of competence in learning than first-year students studying for their first degree. Students' meta-learning competence develops dynamically over the course of their studies.

\section{PARTICIPANTS}

The participants in the present study included 250 Polish students of early-childhood education (15 males and 235 females). The students were in their first year of studies towards the degree of licencjat (group A) and their first year of studies for the degree of magister (group B) at the Faculty of Pedagogy, and had declared their intention to continue their education in preparation for becoming teachers in kindergartens and in grades I-III of elementary school ${ }^{4}$. The average age of students participating in the study was 20.6 years. The average age of students in group a was 19.6 years, in group B it was 22.5 years. All the participants were adults and were over 18 years of age.

\section{INSTRUMENTS}

\section{QUESTIONNAIRE OF THE NEED FOR COGNITION}

Numerous studies on the need for cognition use Cacioppo and Petty's Need For Cognition Scale (NCS) (1982), which allows one to determine the level of the tendency to derive pleasure from performing tasks requiring cognitive activities

4 For the purpose of this research project participants were also tested with research tools not discussed in this report. More information on the above can be obtained directly from the authors. 
(Cazan, 2016). The NCS is a self-report instrument. There exist two versions of the questionnaire: one comprises 34 items and the other, shortened, comprises 18 (Cacioppo \& Petty, 1982, Cacioppo, Petty, \& Kao, 1984; Cazan, 2016; Sadowski, 1993). Research confirms that it represents a univariate scale and that there are no significant differences in the results obtained by females and males (Sadowski, 1993).

In the study presented here we used the Questionnaire of the Need for Cognition (Matusz, Traczyk, \& Gąsiorowska, 2011) which is an adaptation of the original NCS. The questionnaire was modified and verified by Matusz, Traczyk and Gąsiorowska (2011) for the purpose of studying the need for cognition in university students. The team attempted to generate test items which would capture students' responses to a variety of situations necessitating cognitive effort. These include primarily the circumstances in which a person can choose whether to collect information, analyze available arguments, generalize from past experience, and synthesize ideas into more general concepts. Participants responded to items on a 5-point Likert-type scale ranging from 1 (extremely uncharacteristic) to 5 (extremely characteristic). The team developing the Polish version generated 36 test items which were subject to factor analysis with the Varimax rotation method $(\mathrm{KMO}=0.585)$, Bartlett's test for sphericity $x^{2}(1953)=3243.9 ; \mathrm{p}<0.00$. The analysis of the scree plot suggested that a univariate solution should be employed. The questionnaire's internal consistency measured with Cronbach's alpha was $\alpha=0.892$, which testifies to high scale homogeneity. The hypothesised univariate solution was confirmed with confirmatory factor analysis. The research also confirmed the reliability and validity of the rating scale and high test-retest reliability (Matusz, Traczyk, \& Gąsiorowska, 2011, pp. 113-128).

\section{COMPETENCE OF META-LEARNING}

At the first stage of the research, the relevant literature was thoroughly investigated and 80 test items were written. To ensure the validity of the instrument My Learning Strategy - MLS [“Mój system uczenia się”, (MSU)] (Uszyńska-Jarmoc, Żak-Skalimowska, 2015) the questionnaire was tested on a group of 250 university students. The data were collected by means of a 64-item Likert scale of meta-learning developed by the researcher: I totally disagree (1), I disagree (2), I have no opinion (3), I partly agree (4), I agree (5). The scale's adequacy measured by the Kaiser-Meyer-Olkin (KMO) test was 0.72, which is adequate. Bartlett's test for sphericity was also shown to be significant: $\mathrm{p}<0.00$, which means that there was indeed a correlation between the items, thus allowing us to run factor analysis. Exploratory factor analysis performed by the method of principal 
component analysis with oblique (non-orthogonal) rotation (Oblimin - 0.002) produced 4 main components whose eigenvalue was greater than one. They explained $65.484 \%$ of the total variance, which shows that the components were strong. Next, the number of statements was reduced. From the list of 64 items, only those whose factor loadings were lower than 0.40 were selected. Analysis of the content of individual items allowed them to be assigned to four subscales: 1) general knowledge of human learning, 2) awareness of the challenges involved in one's own learning 3) learning skills (planning, implementing and evaluating the results of learning), and 4) attitudes toward learning. 26 questions remained, forming the scale: factor 1 - knowledge - 6 items; factor 2 - awareness -8 items; factor 3 - skills - 6 items, factor 4 - attitudes - 6 items. In addition, with the use of Cronbach's Alpha consistency index the questionnaire was shown to have a reliability index of $\alpha=0.59$ for knowledge, $\alpha=0.69$ for self-awareness, $\alpha=0.67$ for skills, and $\alpha=0.65$ for attitudes. There is also evidence of high validity of the scale used in the My Learning Strategy questionnaire.

\section{ANALYSES/PROCEDURES}

Permission to carry out the study was obtained from the relevant university departments. Students participated in the research voluntarily. Prior to the administration of the scales, all participants were informed about the purpose of the study. The relationship between the two constructs of interest (need for cognition and meta-learning competence) and their sub-dimensions were tested using the Pearson correlation coefficient at a .01 probability level.

\section{RESULTS}

Descriptive information about the groups participating in the study is shown in Table 1 . The results of the study revealed that the level of need for cognition among university students in their first and second cycle of study (future kindergarten and early-childhood education teachers) is relatively high.

Table 1. Descriptive statistics for the participants' scores on need for cognition

\begin{tabular}{|c|c|c|c|c|c|}
\hline Groups - Stage of education & $\mathbf{N}$ & Minimum & Maximum & Mean & SD \\
\hline Licencjat-level - Group A & 162 & 69 & 176 & 123.42 & 20.24 \\
\hline Magister-level - Group B & 88 & 46 & 180 & 131.11 & 20.18 \\
\hline Total & 250 & 46 & 180 & 126.13 & 21.22 \\
\hline
\end{tabular}


The Kolmogorov-Smirnov (K-S) test shows that the distribution of the variance in both groups participating in the study is normal $\mathrm{N}=250 \mathrm{z}=0.050, \mathrm{p}=0.200$ (licencjat-level students - group a - the value of the Kolmogorov-Smirnov statistic is 0.037 with $p=0.200$, while the value for group $B$ is 0.076 with $p=0.200$ with Lilliefors test for normality). The Student's t-test for unpaired samples showed that the level of cognitive need is indeed statistically higher in group B (participants studying for the degree of magister) than in group a (participants studying for the degree of licencjat): $\mathrm{F}=0.432 ; \mathrm{p}>0.05 ; \mathrm{t}(248)=-2.772 ; \mathrm{p}<0.001$.

Table 2. Descriptive statistics of the participants' scores on meta-learning competence

\begin{tabular}{|r|c|c|c|c|c|c|c|}
\hline & N & Min. & Max. & M & SD & Skewness & Kurtosis \\
\hline Licencjat-level - Group A & 162 & 58 & 168 & 117.95 & 16.61 & -0.026 & -0.393 \\
\hline Magister-level - Group B & 88 & 93 & 161 & 126.15 & 17.64 & -0.269 & -0.421 \\
\hline Total & 250 & 58 & 168 & 120.83 & 17.39 & -0.051 & -0.932 \\
\hline
\end{tabular}

The K-S test confirmed the fact that the variance distribution for meta-learning competence in both groups is normal (for group a the value of the KolmogorovSmirnov statistic is 0.063 with $\mathrm{p}=0.200$, while for group $\mathrm{B}$ the value is 0.085 with $\mathrm{p}=0.158$ ). The Student's t-test for unpaired samples showed that the aggregate result of the study into meta-learning competence is indeed statistically higher in the group of participants studying for the degree of magister than in the group of participants studying for the degree of licencjat: $\mathrm{F}=2.201 ; \mathrm{p}>0.05 ; \mathrm{t}(248)=-3.645 ; \mathrm{p}<0.001$. The Mann-Whitney U rank-sum test revealed that the differences between the scores in meta-learning competence obtained by students from groups a and B are statistically significant $\mathrm{p}<0.05$ (binomial asymptotic distribution).

When Table 4 is examined, significant correlations between dimensions of meta-learning can be seen. Bivariate correlations between subscales (various components of meta-learning) ranged from low to moderate, i.e., .25 to .67.

Table 3. Descriptive statistics for the participants' scores on various components of meta-learning

\begin{tabular}{|l|c|c|c|c|c|c|c|}
\hline Subscales of meta-learning & N & Min. & Max. & M & SD & Skewness & Kurtosis \\
\hline knowledge about learning & 250 & 0.00 & 18.00 & 7.20 & 4.33 & -0.051 & -0.932 \\
\hline awareness of learning & 250 & 6.00 & 24.00 & 16.59 & 3.49 & -0.315 & -0.240 \\
\hline skills of learning & 250 & 2.00 & 18.00 & 11.78 & 2.90 & -0.162 & -0.036 \\
\hline attitudes towards learning & 250 & 4.00 & 18.00 & 10.45 & 2.72 & 0.359 & -0.357 \\
\hline
\end{tabular}


Table 4. Investigation of the relationship among various components of meta-learning

\begin{tabular}{|l|c|c|c|c|}
\hline \multicolumn{1}{|c|}{ subscales } & knowledge & awareness & skills & attitudes \\
\hline knowledge & 1 & $0.375^{* *}$ & $0.287^{* *}$ & $0.246^{* *}$ \\
\hline awareness & & 1 & $0.675^{* *}$ & $0.573^{* *}$ \\
\hline skills & & & 1 & $0.627^{* *}$ \\
\hline attitudes & & & & 1 \\
\hline
\end{tabular}

The scores on performance assessment measuring meta-learning competence obtained by younger participants (students in the licencjat group - Group A) were compared with those obtained by older participants (students in the magister group - Group B). a comparison of the data obtained reveals that within all subscales, students working towards the degree of magister scored higher than students working towards the degree of licencjat (first cycle of study). The greatest differences between the groups of students compared concerned self-awareness and awareness of major challenges faced in one’s own learning and human learning in general.

Table 5. Descriptive statistics for the participants' scores on various components of meta-learning - Licencjat group - Group A

\begin{tabular}{|l|c|c|c|c|c|c|c|}
\hline \multicolumn{1}{|c|}{ subscales } & N & Min. & Max. & M & SD & Skewness & Kurtosis \\
\hline knowledge & 162 & 0.00 & 15.00 & 6.55 & 4.14 & 0.030 & -0.924 \\
\hline awareness & 162 & 6.00 & 24.00 & 15.78 & 3.40 & -0.246 & -0.311 \\
\hline skills & 162 & 2.00 & 18.00 & 11.33 & 2.82 & -0.174 & 0.390 \\
\hline attitudes & 162 & 4.00 & 18.00 & 10.11 & 2.59 & 0.445 & -0.040 \\
\hline
\end{tabular}

Table 6. Descriptive statistics for the participants' scores on various components of meta-learning - Magister group - Group B

\begin{tabular}{|l|c|c|c|c|c|c|c|}
\hline \multicolumn{1}{|c|}{ subscales } & N & Min. & Max. & M & SD & Skewness & Kurtosis \\
\hline knowledge & 88 & 0.00 & 18.00 & 8.41 & 4.43 & -0.300 & -0.815 \\
\hline awareness & 88 & 8.00 & 24.00 & 18.10 & 3.14 & -0.481 & 0.245 \\
\hline skills & 88 & 6.00 & 18.00 & 12.59 & 2.87 & -0.220 & -0.675 \\
\hline attitudes & 88 & 5.00 & 18.00 & 11.09 & 2.84 & 0.160 & -0.683 \\
\hline
\end{tabular}

Using the Student's t-test for unpaired samples we established that the results for the assessment of students' knowledge about human learning are indeed significantly higher in the group of students working towards the degree of magister than in the group of students working towards the degree of licencjat: $F=0.747$; $\mathrm{p}>0.05 ; \mathrm{t}(248)=-3.305 ; \mathrm{p}<0.001$. The results of the research into the students' self-awareness with regard to the process and results of learning are also higher 
in the group of students working towards the degree of magister than in the group working towards the degree of licencjat: $\mathrm{F}=1.662 ; \mathrm{p}>0.05 ; \mathrm{t}(248)=-5.298$; $\mathrm{p}<0.001$. Students working towards the degree of magister display better learning skills than students working towards the degree of licencjat: $\mathrm{F}=0.806 ; \mathrm{p}>0.05$; $\mathrm{t}(248)=-3.325 ; \mathrm{p}<0.001$. a positive attitude towards learning is also shown to be stronger in students working towards the degree of magister than in students working towards their licencjat: $\mathrm{F}=1.217 ; \mathrm{p}>0.05 ; \mathrm{t}(248)=-2.753 ; \mathrm{p}<0.005$.

The results of the study indicate a statistically significant correlation between the need for cognition and all the components of meta-learning competence among the students at the Faculty of Pedagogy and Psychology at the University of Białystok who comprised the sample studied. The results can be explained by examining the nature of cognition, which is a part of metacognitive thinking (Daghistani, 2015). The strongest correlation was observed between need for cognition and attitude towards learning $(r=.544, \mathrm{p}<.01)$.

Table 7. Investigating the relationship between need for cognition and meta-learning in students of early-childhood education

\begin{tabular}{|c|c|}
\hline & need for cognition \\
\hline knowledge & $0.189^{* *}$ \\
\hline awareness & $0.429^{* *}$ \\
\hline skills & $0.397^{* *}$ \\
\hline attitudes & $0.544^{* *}$ \\
\hline
\end{tabular}

Note: ${ }^{*} p<0.05 ;{ }^{* *} p<0.01$

\section{CONCLUSIONS AND DISCUSSION}

We think of our societies as "knowledge societies", where lifelong learning is becoming increasingly important. Lifelong learning refers to the idea that people learn all their lives, not only in schools and universities but also in non-formal and informal ways (Steffens, 2015). The teacher's professional development is made possible by the ability to learn and consciously direct his/her own learning process, not only within a social network, but also with regard to the Internet (Aksal, Gazi, \& Bahçelerli, 2013; Siemens, 2005; Pankhurst, 2010; Starkey, 2010). In our research we wanted to investigate the existence of a link between cognitive need and meta-learning competence in students studying for the profession of teachers in early-education at the Faculty of Pedagogy. Our assumption was that both qualities are developmental in character; therefore, since students at the magister- 
level of education have spent a longer period studying and preparing for the teaching profession, their cognitive need might be expected to be stronger and their meta-learning competence higher. The study confirmed the proposed differences between students at different levels of education. It also showed that need for cognition correlates positively with level of meta-learning competence. Similar dependencies were also revealed by research conducted by Daghistani (2015).

Perfecting the professional competencies of future teachers is made possible by developing their meta-learning competence. The latter depends on whether the subject experiences joy and derives satisfaction in tackling cognitively-interesting problems, that is, whether s/he has a high level of motivation for independent development and growth. Research carried out by Sariçam (2015) on a group of Turkish university students enrolled in different departments of the Education Faculty confirmed the existence of a link between metacognition, happiness and the mediating role of stress. Sariçam's findings are especially important in terms of their potential implications for the process of higher education.

\section{IMPLICATIONS FOR TEACHER EDUCATION}

The research presented in this text shows that meta-learning competence develops over the course of a person's studies, and its precondition is, inter alia, the student's high level of cognitive need. Therefore, in order that candidates for teachers in early-education learn to be responsible for their own development, it may be worth extending the compulsory period of education for obtaining a teaching degree to five years (at present it is possible to obtain a teaching qualification upon completion of the first cycle of education and graduating with the licencjat). It should also be emphasized that teacher's development should move away from being teacher-centred and content-focused towards an education system where the university can deliver differentiated and customized learning to groups of students, individuals within these groups, and/or particular individuals in a student-mentor situation. Only teaching practice, serving as a source of critical reflection and sharing of experiences among team members, can be considered as conducive to the actual, full development of teachers' professionalism (Postholm, 2012; Roblin \& Margalef, 2013; Ronfeldt, Farmer, McQueen, \& Grissom, 2015). The change in the nature of education from the kind of teaching which resembles a monologue or is a sort of "reflective" education to a form of teaching which resembles dialogue is based on providing students with opportunities to learn about the surrounding world which derive from their personal characteristics. Herein lies the meaning and content of heuristic learning - the process in which each student builds his/her own autonomy, learning in dialogue with the cultural and historical analogue - the 
achievements of human culture. It is in fact the matter of the learner realizing his/her inborn potential: the embodiment of the principle of human relevance in education (Khutorskoy, 2010).

\section{LIMITATIONS AND FURTHER RESEARCH}

We recognize three limitations in this research. First, the sample was small and consisted only of university students. Secondly, all the candidates for the teaching profession who participated in the study attended the same university, which is why the results obtained cannot be generalised. Finally, research into the students' meta-learning competence involved students rather than newly-qualified teachers. It is advisable that the study be repeated in the same group of students once they have worked for a few years in the teaching profession. It is possible that learning in the course of one's own educational practice will be quite different from learning at university, because at university students obtain knowledge from sources other than direct teaching practice, while as newly qualified teachers of young children they encounter numerous difficulties (Bruinsma \& Jansen, 2010). While at university, future teachers gain pedagogical knowledge which comes from three sources: social transmission, personal experience, and personal reflection; one must, however, emphasize that social transmission is the most frequently used of the three. Social transmission comprises information obtained from other people, acquired while studying written sources, and learned from the Internet and other media. Experience, another source of knowledge, is gained by analysing one's own actions and personal relations with others, and observing what others do. As a source of pedagogical knowledge, reflection stems from self-assessment of personal experience as a kind of “introspection”; from other people’s judgments and opinions and one's own judgments and opinions about other people; and from the desire to construct one's own theories. It is therefore worth designing a study to investigate the ways in which the correlation between the level of cognitive need and the results of learning and building meta-learning competence depend on the choice of the aforementioned sources of pedagogical knowledge. a study of this kind would, however, be experimental rather than diagnostic, due to its correlational nature. It may also be worth conducting similar research with a group of newly qualified teachers, since, as emphasized by Cacioppo and others (1996), the need for cognition changes and is modified throughout one's life. 


\section{References}

Aksal, F.A., Gazi, Z.A., \& Bahçelerli, N.M. (2013). Practice of Connectivism as Learning Theory: Enhancing Learning Process Through Social Networking Site (Facebook). Gaziantep University Journal of Social Sciences, 12(2), pp. 243-252.

Arpaci, D., \& Bardakçi, M. (2016). An Investigation on the Relationship between Prospective Teachers' Early Teacher Identity and Their Need for Cognition. Journal of Education and Training Studies, 4(3), pp. 9-19. DOI: 10.11114/jets.v4i3.1176.

Auerbach, S. (2015). STEM Teaching: The Need for Wider Skills. Nature, 524, p. 291. DOI: 10.1038/524291c.

Biesta, G. (2012). The Future of Teacher Education: Evidence, Competence or Wisdom? Research on Steiner Education, 3(1), pp. 8-22.

Biggs, J.B. (1985). The Role of Meta-learning in Study Process. British Journal of Educational Psychology, 55(3), pp. 185-212. DOI: 10.1111/j.2044-8279.1985.tb02625.x.

Boix Mansilla, V., \& Duraising, E.D. (2007). Targeted Assessment of Students' Interdisciplinary Work: An Empirically Grounded Framework Proposed. The Journal of Higher Education, 78(2), pp. 215-237.

Bruinsma, M., \& Jansen, E.P.W.A. (2010). Is the Motivation to Become a Teacher Related to Pre-service Teachers’ Intentions to Remain in the Profession? European Journal of Teacher Education, 33(2), pp. 185-200. DOI: 10.1080/02619760903512927.

Bruner, J. (1996). The Culture of Education. Cambridge, MA: Harvard University Press.

Cacioppo, J.T., \& Petty, R.E. (1982). The Need for Cognition. Journal of Personality and Social Psychology, 42(1), pp. 116-131.

Cacioppo, J.T., Petty, R.E., Feinstein, J.A., \& Jarvis, W.B.G. (1996). Dispositional Differences in Cognitive Motivation: The Life and Times of Individuals Varying in Need for Cognition. Psychological Bulletin, 119(2), pp. 197-253.

Cacioppo, J.T., Petty, R.E., \& Kao, C F. (1984). The Efficient Assessment of Need for Cognition. Journal of Personality Assessment, 48(3), pp. 306-307. DOI: 10.1207/s15327752jpa4803_ 13.

Carneiro, R. (2007). The Big Picture: Understanding Learning and Meta-learning Challenges. European Journal of Education, 42(2), pp. 151-172. DOI: 10.1111/j.1465-3435.2007.00303.x.

Carneiro, R. (2011). Discovering the treasure of learning. In: Yang, J. \& Valdes-Cotera, R. (Eds.), Making lifelong learning a reality for all: Conceptual evolutions and policy developments. Hamburg: UNESCO Institute for Lifelong learning, 3-2.

Carnevale, J.J., Inbar, Y., \& Lerner, J.S. (2011). Individual Differences in Need for Cognition and Decision-making Competence among Leaders. Personality and Individual Differences, 51(3), pp. 274-278. DOI: 10.1016/j.paid.2010.07.002.

Cazan, A.M. (2016). The Factor Structure of the Short Need for Cognition Scale. Bulletin of the Transilvania University of Braşov, Series VII: Social Sciences, Law, 9(58), pp. 19-28.

Clarà, M., \& Barberà, E. (2014). Three Problems with the Connectivist Conception of Learning. Journal of Computer Assisted Learning, 30(3), pp. 197-206. DOI: 10.1111/jcal.12040.

Clark, S.G., \& Wallace, R.L. (2015). Integration and Interdisciplinarity: Concepts, Frameworks, and Education. Policy Sciences, 48(2), pp. 233-255. DOI: 10.1007/s11077-0159210-4. 
Daghistani, B. (2015). Level of Need for Cognition and Metacognitive Thinking Among Undergraduate Kindergarten Female Students at King Sa’ud University in Sa'udi Arabia. Education, 136(1), pp. 101-111.

Deci, E.L., \& Ryan, R.M. (1985). Intrinsic Motivation and Self-Determination in Human Behavior. New York, NY: Plenum.

Del Barrio-Garcia, S., Arquero-Montaño, J.L., \& Romero-Frias, R. (2015). Personal Learning Environments Acceptance Model: The Role of Need for Cognition, e-Learning Satisfaction and Students' Perceptions. Educational Technology and Society, 18(3), pp. 129-141.

Efklides, A. (2014). How Does Metacognition Contribute to the Regulation of Learning? An Integrative Approach. Psychological Topics, 23(1), pp. 1-30.

Farrell, T.S., \& Jacobs, G.M.L. (2016). Practicing What We Preach: Teacher Reflection Groups on Cooperative Learning. The Electronic Journal for English as a Second Language, 19(4), pp. 1-9.

Flavell, J.H. (1979). Metacognition and Cognitive Monitoring: a New Area of CognitiveDevelopmental Inquiry. American Psychologist, 34(10), pp. 906-911. DOI: 10.1037/0003066X.34.10.906.

Flavell, J.H., Green, F.L., \& Flawell, E.R. (1998). The Mind Has a Mind of Its Own: Developing Knowledge about Mental Uncontrollability. Cognitive Development, 13(1), pp. 127-138. DOI: 10.1016/S0885-2014(98)90024-7.

Fleischhauer, M., Strobel, A., Enge, S., \& Strobel, A. (2013). Assessing Implicit Cognitive Motivation: Developing and Testing an Implicit Association Test to Measure Need for Cognition. European Journal of Personality, 27(1), pp. 15-27. DOI: 10.1002/per.1841.

Fox, R. (2001). Constructivism Examined. Oxford Review of Education, 27(1), pp. 23-35. DOI: $10.1080 / 03054980125310$.

Gaikhorst, L., Beishuizen, J., Roosenboom, B., \& Volman, M. (2017). The Challenges of Beginning Teachers in Urban Primary Schools. European Journal of Teacher Education, 40(1), pp. 46-61. DOI: 10.1080/02619768.2016.1251900.

Gauthier, K.J., Christopher, A.N., Walter, M.I., Mourad, R., \& Marek, P. (2006). Religiosity, Religious Doubt, and the Need for Cognition: Their Interactive Relationship with Life Satisfaction. Journal of Happiness Studies, 7(2), pp. 139-154.

Gergen, K.J. (1995). Social Construction and the Educational Process. In: L.P. Steffe \& J. Gale (Eds.), Constructivism in Education (pp. 17-39). Hillsdale, N.J.: Lawrence Erlbaum Associates.

Gottfried, A.E. (1985). Academic Intrinsic Motivation in Elementary and Junior High School Students. Journal of Educational Psychology, 77(6), pp. 631-645. DOI: 10.1037/00220663.77.6.631.

Haynes, C., \& Brown Leonard, J. (2010). From Surprise Parties to Mapmaking: Undergraduate Journeys Toward Interdisciplinary Understanding. The Journal of Higher Education, 81(5), pp. 645-666.

Heppner, P.P., Reeder, B.L., \& Larson, L.M. (1983). Cognitive Variables Associated with Personal Problem Solving Appraisal: Implications for Counseling. Journal of Counseling Psychology, 30(4), pp. 537-545. DOI: 10.1037/0022-0167.30.4.537.

Jackson, N. (2004). Developing the Concept of Meta-learning. Innovations in Education and Teaching International, 41(4), pp. 391-403. 
Jakobi, A.P., \& Rusconi, A. (2009). Lifelong Learning in the Bologna Process: European Developments in Higher Education. Compare: a Journal of Comparative and International Education, 39(1), pp. 51-65.

Kara, A. (2009). The Effect of a 'Learning Theories' Unit on Students' Attitudes Toward Learning. Australian Journal of Teacher Education, 34(3), pp. 100-112. DOI: 10.14221/ ajte.2009v34n3.5.

Kelchtermans, G. (2009). Who I am in How I Teach Is the Message. Self-Understanding, Vulnerability and Reflection. Teachers and Teaching: Theory and Practice, 15(2), pp. 257-272. DOI: 10.1080/13540600902875332.

Kelly, D., \& Donaldson, D.I. (2016). Investigating the Complexities of Academic Success: Personality Constrains the Effects of Metacognition. The Psychology of Education Review, 40(2), pp. 17-24.

Khutorskoy, A.V. (2010). Printsip chelovekosoobraznosti i ego rol v obnovlenii obrazovaniya. Tezisy vystupleniya na Byuro Otdeleniya filosofii obrazovaniya i teoreticheskoy pedagogiki RAO -Talking Points at the Bureau of the Philosophy of Education and Theoretical Pedagogy RAO. Retrieved from: http://www.khutorskoy.ru/be/2010/0601/index.htm.

Koch, C.(2003). Self-monitoring, Need forCognition, and theStroopEffect: a Preliminary Study. Perceptual and Motor Skills, 96(1), pp. 212-214. DOI: 10.2466/pms.2003.96.1.212.

Lamote, C., \& Engels, N. (2010). The Development of Student Teachers’ Professional Identity. European Journal of Teacher Education, 33(1), pp. 3-18. DOI: 10.1080/0261976090345 7735.

Matusz, P.J., Traczyk, J., \& Gąsiorowska, A. (2011). Questionnaire. Need for Cognition - Design and Empirical Verification of a Tool Measuring Cognitive Motivation. Psychologia Społeczna, 6(2), pp. 113-128.

McGlynn-Stewart, M. (2015). From Student to Beginning Teacher: Learning Strengths and Teaching Challenges. Cogent Education, 2(1), pp. 1-18. DOI: 10.1080/2331186X.2015. 1053182.

McMahon, T. (1999). Using negotiation in summative assessment to encourage critical thinking. Teaching in Higher Education, 4(4), pp. 549-554.

Miller, M.L., Omens, R.S., \& Delvadia, R. (1991). Dimensions of Social Competence: Personality and Coping Style Correlates. Personality and Individual Differences, 12(9), pp. 955-964. DOI: 10.1016/0191-8869(91)90185-E.

Njus, D., \& Johnson, D.R. (2008). Need for Cognition as a Predictor of Psychosocial Identity Development. The Journal of Psychology, 142(6), pp. 645-655. DOI: 10.3200/ JRLP.142.6.645-655.

Osberg, T.M. (1987). The Convergent and Discriminant Validity of the Need for Cognition Scale. Journal of Personality Assessment, 51(3), pp. 441-450.

Palincsar, A.S. (1998). Social Constructivist Perspectives on Teaching and Learning. Annual Review of Psychology, 49(1), pp. 345-375. DOI: 10.1146/annurev.psych.49.1.345.

Panitz, T., \& Panitz, P. (1996). Encouraging the Use of Collaborative Learning in Higher Education. Retrieved from: http://home.capecod.net/ tpanitz/tedsarticles/encouragingcl.htm (accessed: April 10, 2017).

Pankhurst, K.V. (2010). Learning by Experience, Work and Productivity: Theory and Empirical Evidence. Journal of Vocational Education and Training, 62(2), pp. 103-122. DOI: 10.1080/13636821003690504. 
Pillen, M., Beijaard, D., \& den Brok, P. (2013). Professional Identity Tensions of Beginning Teachers. Teachers and Teaching: Theory and Practice, 19(6), pp. 660-678. DOI: 10.108 0/13540602.2013.827455.

Postholm, M.B. (2012). Teachers’ Professional Development: a Theoretical Review. Educational Research, 54(4), pp. 405-429.

Reinhard, M.A. (2010). Need for Cognition and the process of lie detection. Journal of Experimental Social Psychology, 46 (6), pp. 961-971.

Roblin, P.N., \& Margalef, L. (2013). Learning from Dilemmas: Teacher Professional Development Through Collaborative Action and Reflection. Teachers and Teaching: Theory and Practice, 19(1), pp. 18-32. DOI: 10.1080/13540602.2013.744196.

Ronfeldt, M., Farmer, S.O., McQueen, K., \& Grissom, J.A. (2015). Teacher Collaboration in Instructional Teams and Student Achievement. American Educational Research Journal, 52(3), pp. 475-514. DOI: 10.3102/0002831215585562.

Rosenberg, M. (1965). Society and the Adolescent Self-Image. Princeton, NJ: Princeton University Press.

Ryan, R.M., \& Deci, E.L. (2000). Intrinsic and Extrinsic Motivations: Classic Definitions and New Directions. Contemporary Educational Psychology, 25(1), pp. 54-67. DOI: 10.1006/ ceps.1999.1020.

Sadowski, C.J. (1993). An Examination of the Short Need for Cognition Scale. The Journal of Psychology, 127(4), pp. 451-454. DOI: 10.1080/00223980.1993.9915581.

Sadowski, C.J., \& Gulgoz, S. (1992a). Association of Need for Cognition and Course Grades. Perceptual and Motor Skills, 74(2), p. 498. DOI: 10.2466/pms.1992.74.2.498.

Sadowski, C. J., \& Gulgoz, S. (1992b). Internal Consistency and Test-Retest Reliability of the Need for Cognition Scale. Perception and Motor Skills, 74(2), p. 610. DOI: 10.2466/ pms.1992.74.2.610.

Sariçam, H. (2015). Metacognition and Happiness: The Mediating Role of Perceived Stress. Studia Psychologica, 57(4), pp. 271-283. DOI: 10.21909/sp.2015.03.699.

Scager, K., Akkerman, S.F., Pilot, A., \& Wubbels, T. (2012). Challenging High-Ability Students. Studies in Higher Education, 39(4), pp. 659-679. DOI: 10.1080/03075079.2012.743117.

Scager, K., Akkerman, S.F., Pilot, A., \& Wubbels, T. (2017). Teacher Dilemmas in Challenging Students in Higher Education. Teaching in Higher Education, 22(3), pp. 318-335. DOI: 10.1080/13562517.2016.1248392.

Scott, C.L. (2015). THE FUTURES of LEARNING 2: What Kind of Learning for the 21st Century? UNESCO, Education Research and Foresight, Paris. [ERF Working Papers Series 14, pp. 1-14].

Siemens, G. (2005). Connectivism: a Learning Theory for the Digital Age. International Journal of Instructional Technology and Distance Learning, 2(1), pp. 3-10.

Snider, V., \& Roehl, R. (2007). Teachers’ Beliefs about Pedagogy and Related Issues. Psychology in the Schools, 44(8), pp. 873-886.

Spelt, E.J., Luning, P.A., van Boekel, M.A, \& Mulder, M. (2017). a Multidimensional Approach to Examine Student Interdisciplinary Learning in Science and Engineering in Higher Education. European Journal of Engineering Education, 42(6), pp. 761-774. DOI: 10.1080/03043797.2016.1224228. 
Starkey, L. (2010). Teachers’ Pedagogical Reasoning and Action in the Digital Age. Teachers and Teaching: Theory and Practice, 16(2), pp. 233-244. DOI: 10.1080/13540600903478 433.

Steffens, K. (2015). Competences, Learning Theories and MOOCs: Recent Developments in Lifelong Learning. European Journal of Education, 50(1), pp. 41-59. DOI: 10.1111/ ejed.12102.

Stevanovic, D., Lalic, B., Batinic, J., Damjanovic, R., \& Jovic, V. (2016). Metacognitions Questionnaire for Children: Development and Validation of the Serbian Version. Journal of Evidence-Based Psychotherapies, 16(2), pp. 135-151.

Tolentino, E., Curry, L. \& Leak, G. (1990). Further Validation of the Short Form of the Need for Cognition Scale. Psychological Reports, 66, pp. 321-322. DOI: 10.2466/ $\operatorname{pr} 0.1990 .66 .1 .321$.

Trumbull, E., \& Pacheco, M. (2005). The Teacher's Guide to Diversity: Building a Knowledge Base. Providence: The Education Alliance at Brown University.

Uszyńska-Jarmoc, J. (in print). The Level of Self-esteem and Competence of Metalearning with its Dimensions and Educational Achievement of First Year High School Students.

Uszyńska-Jarmoc, J., Żak-Skalimowska M. (2015). My Learning Strategy Questionnaire (unpublished).

Waters, L.K., \& Zakrajsek, T. (1990). Correlates of Need for Cognition Total and Subscale Scores. Education and Psychological Measurement, 50(1), pp. 213-217. DOI: 10.1177/00 13164490501026.

Wells, A., \& Cartwright-Hatton, S. (2004). a Short Form of the Metacognitions Questionnaire: Properties of the MCQ-30. Behaviour Research and Therapy, 42(4), pp. 385-396. DOI: 10.1016/S0005-7967(03)00147-5.

Wood, S.L., \& Swait, J. (2002). Psychological Indicators of Innovation Adoption: Cross-Classification Based on Need for Cognition and Need for Change. Journal of Consumer Psychology, 12(1), pp. 1-13. DOI: 10.1207/S15327663JCP1201_01.

Yoon, H.G., \& Kim, M. (2010). Collaborative Reflection through Dilemma Cases of Science Practical Work during Practicum. International Journal of Science Education, 32(3), pp. 283-301. DOI: 10.1080/09500690802516538. 